University of Chicago Law School

Chicago Unbound

Journal Articles

Faculty Scholarship

1977

\title{
State Taxation and the Supreme Court: Toward a More Unified Approach to Constitutional Adjudication
}

Walter Hellerstein

Follow this and additional works at: https://chicagounbound.uchicago.edu/journal_articles

Part of the Law Commons

\section{Recommended Citation}

Walter Hellerstein, "State Taxation and the Supreme Court: Toward a More Unified Approach to Constitutional Adjudication," 75 Michigan Law Review 1426 (1977).

This Article is brought to you for free and open access by the Faculty Scholarship at Chicago Unbound. It has been accepted for inclusion in Journal Articles by an authorized administrator of Chicago Unbound. For more information, please contact unbound@law.uchicago.edu. 


\section{STATE TAXATION AND THE SUPREME COURT: TOWARD A MORE UNIFIED APPROACH TO CONSTITUTIONAL ADJUDICATION?}

\section{-Walter Hellerstein ${ }^{*} \dagger$}

The Supreme Court's decisions delineating the constitutional limitations on state tax power have often defied rational analysis. The Court read the commerce clause ${ }^{1}$ as forbidding a state tax on the privilege of doing interstate business ${ }^{2}$ but not on the privilege of doing interstate business in corporate form. ${ }^{3}$ It construed the import-export clause ${ }^{4}$ as prohibiting a state tax on bales of imported hemp awaiting use in manufacturing ${ }^{5}$ but not on piles of imported ore and plywood awaiting such use. ${ }^{6}$ It interpreted the supremacy clause $^{7}$ as barring a state tax upon the sale of goods to one government contractor ${ }^{8}$ but not to another ${ }^{9}$ because the second was not deemed to be a purchasing agent for the federal government, even though in both instances the federal government bore the economic burden of the tax and ultimately took title to the goods. Indeed, the Court itself came to recognize that consistency was not the hallmark of its pronouncements in this field, ${ }^{10}$ that form occasionally prevailed over substance, ${ }^{11}$ and that "[t]o attempt to harmonize all that has been said in the past would neither clarify what has gone before nor guide the future." 12

* Assistant Professor of Law, The University of Chicago. A.B. 1967, Harvard University; J.D. 1970, The University of Chicago.--Ed.

t The author would like to thank Walter J. Blum, Gerhard Casper, and Phil C. Neal for their helpful comments on an earlier draft of this article.

1. U.S. Const. art. I, \& 8, cl. 3.

2. See Spector Motor Serv., Inc. v. O'Connor, 340 U.S. 602 (1951).

3. See Colonial Pipeline Co. v. Traigle, 421 U.S. 100 (1975). See generally W. Hellerstein, State Taxation of Interstate Business and the Supreme Court, 1974 Term: Standard Pressed Steel and Colonial Pipeline, 62 VA. L. REv. 149, $176-88$ (1976).

4. U.S. CONST. art. I, $\$ 10$, cl. 2; see note 20 infra.

5. See Hooven \& Allison Co. v. Evatt, 324 U.S. 652 (1945).

6. See Youngstown Sheet \& Tube Co. v. Bowers, 358 U.S. 534 (1959). See generally W. Hellerstein, Michelin Tire Corp. v. Wages: Enhanced State Power To Tax Imports, 1976 SUP. CT. REV. 99.

7. U.S. CoNsT. art. VI, cl. 2.

8. See Kern-Limerick, Inc. v. Scurlock, 347 U.S. 110 (1954).

9. See Alabama v. King \& Boozer, 314 U.S. 1 (1941).

10. See Northwestern States Portland Cement Co. v. Minnesota, 358 U.S. 450, 458 (1959); Miller Bros. Co. v. Maryland, 347 U.S. 340, 344 (1954).

11. See Kern-Limerick, Inc. v. Scurlock, 347 U.S. 110, 122-23 (1954).

12. Freeman v. Hewit, 329 U.S. 249, 252 (1946). 
In light of the difficulties in generalizing about the Court's precedents regarding particular constitutional limitations on state tax power, generalizations embracing decisions directed to several separate limitations are especially suspect since they aggravate the danger of oversimplifying problems that have been resolved for years on the basis of razor-thin factual distinctions and ephemeral doctrinal nuances. ${ }^{13}$ Nevertheless, with due regard for the hazards of speculation in this area, there are grounds for suggesting that the Court is moving toward a more systematic approach to interpretation of those constitutional inhibitions on state taxation that, broadly speaking, bear on the allocation of powers between state and national governments in our federal system. ${ }^{14}$ The evidence for this hypothesis-several recent decisions handed down by the Court over a relatively brief period-is admittedly fragmentary, but it is sufficient to warrant a preliminary inquiry and some tentative conclusions.

The first section of this Article examines three recent cases, each addressed to a different constitutional limitation on the scope of state tax power, that may be read as signifying a new approach: Michelin Tire Corp. v. Wages, ${ }^{15}$ which concerned the import-export clause; ${ }^{16}$ United States $v$. County of Fresno, ${ }^{17}$ which concerned the supremacy clause; and Complete Auto Transit, Inc. v. Brady, ${ }^{18}$ which concerned the commerce clause. Section II considers the implications of these decisions and explores the possibility that they share an underlying doctrinal unity.

\section{The Court's Decisions}

\section{A. Michelin Tire Corp. v. Wages ${ }^{10}$}

In Michelin, the Supreme Court abandoned a century of precedent in holding that the import-export clause does not bar a state from imposing a nondiscriminatory ad valorem property tax on im-

13. See W. Hellerstein, Some Reflections on the State Taxation of a Nonresident's Personal Income, 72 Mich. L. REv. 1309, 1309-10 \& nn.1-10 (1974); W. Hellerstein, supra note 6; W. Hellerstein, supra note 3 . The Court has explicitly warned against the dangers of overgeneralizing in this manner. See, e.g., Richfield Oil Corp. v. State Bd. of Equalization, 329 U.S. 69, 75-76 (1946).

14. Other restraints on the states' power of taxation-those arising out of the due process and equal protection clauses of the fourteenth amendment and the privileges and immunities clause of article IV-constitute limitations that relate primarily to concerns other than the allocation of authority between state and federal governments.

15. 423 U.S. 276 (1976).

16. See note 20 infra.

17. 97 S. Ct. 699 (1977).

18. 97 S. Ct. 1076 (1977).

19. The following discussion draws freely from my article, supra note 6 . 
ported goods. In so holding, the Court returned to the original purposes of the clause and revised the analytical framework for determining when a state tax is a forbidden "impost" or "duty" on imports. $^{20}$

Michelin Tire Corporation, an importer and wholesale distributor in the United States of automobile and truck tires manufactured in France and Canada, brought suit in a Georgia state court to contest the constitutionality of ad valorem property taxes levied upon Michelin's inventory of imported tires stored in a warehouse pending distribution. $^{21}$ Michelin argued that the tires were immune from property taxes under the import-export clause.

The Georgia courts, following settled principles of adjudication under the import-export clause, analyzed the validity of the tax by addressing the question whether the tires had retained their status as imports when the tax was assessed. The trial court determined that the tires had retained such status ${ }^{22}$ on the basis of its reading of the classic formulation from Brown v. Maryland: ${ }^{23}$

It is sufficient for the present to say, generally, that when the importer has so acted upon the thing imported that it has become incorporated and mixed up with the mass of property in the country, it has, perhaps, lost its distinctive character, as an import, and has become subject to the taxing power of the State; but while remaining the property of the importer, in his warehouse, in the original form or package in which il was imported, a tax upon it

20. The complete text of the clause reads:

No State shall, without the Consent of the Congress, lay any Imposts or Duties on Imports or Exports, except what may be absolutely necessary for executing it's inspection Laws: and the net Produce of all Duties and Imposts, laid by any State on Imports or Exports, shall be for the Use of the Treasury of the United States; and all such Laws shall be subject to the Revision and Controul of the Congress.

U.S. CoNST. art. I, $\$ 10, \mathrm{cl} .2$.

21. Michelin also imported automobile and truck tire tubes. The taxation of these items was at issue in the state courts but not in the Supreme Court. That issue will not be considered here, but it is discussed in W. Hellerstein, supra note 6, at 101-06.

All real and personal property in Georgia, unless specifically exempted, is subject to taxation. Gs. CODE ANN. \$ 92-101 (1974). The county is authorized to levy taxes for current expenses, accumulated debts, and other county purposes. Gs. CodE ANN. \$\$ 92-3702, -3706, -3707, -3713, -3715, -3717, -3718 (1974). The order assessing the county tax for the year must state the percentage levied for each specific purpose, and the assessment also applies to property taxed by the state. Gı. CoDE ANN. \$ 92-3801 (1974). The county tax authority is obligated to have a statement prepared of the amount of tax required for county purposes each year. GA. Cone ANN. § 92-3709 (1974). All tangible property is assessed at $40 \%$ of the fair market value. GA. CODE ANN. \$ 92-5703 (1974). The tax rate is the aggregate of all lawful levies. State Tax Guide (CCH) $\pi$ 20-354 (1977).

22. Petition for Certiorari at A-4, Michelin Tire Corp. v. Wages, 423 U.S. 276 (1976).

23. 25 U.S. (12 Wheat.) 419 (1827). 
is too plainly a duty on imports to escape the prohibition in the constitution. ${ }^{24}$

On appeal, the Georgia Supreme Court reversed. ${ }^{25}$ After a lengthy exegesis on the "original package" doctrine, the court concluded that the tires, which had been sorted by size and style and commingled with other shipments, had lost their status as imports and, thus, were subject to taxation.

Michelin petitioned the United States Supreme Court for certiorari, and the Court granted the petition. ${ }^{26}$ The only question presented by the parties was the constitutionality under the import-export clause of the assessment of the state property tax upon Michelin's tires, a question both parties framed in terms of the physical packaging, form, and arrangement of the tires. ${ }^{27}$

The Supreme Court affirmed the decision of the Georgia Supreme Court, but on a different ground. It ignored the question whether the state court had accurately drawn the line between taximmune imports and goods that had become "incorporated and mixed up with the mass of property in the country." 28 Instead it ruled that "Georgia's assessment of a nondiscriminatory ad valorem property tax against the imported tires is not within the constitutional prohibition against 'laying any Imposts or Duties on Imports . . .' and that insofar as Low v. Austin, 13 Wall. 29 (1872) is to the contrary, that decision is overruled."29 What induced the Supreme Court to reconsider Low is a matter for speculation, ${ }^{30}$ but its opinion in Michelin marks a fundamental reexamination of the purpose and scope of the import-export clause's prohibition against state taxation of imports. In contrast to its past opinions in this area, which were often characterized by a mechanistic application of Marshall's "original package" language in Brown v. Maryland to determine whether the goods under consideration had ceased to be "imports," 31 the Court's opinion explicitly refrained from addressing the question

24. 25 U.S. (12 Wheat.) at 441-42.

25. Wages v. Michelin Tire Corp., 233 Ga. 712, 214 S.E.2d 349 (1975).

26. 422 U.S. 1040 (1975).

27. Petition for Writ of Certiorari at 2; Respondent's Brief in Opposition to Petition for a Writ of Certiorari at 2. See 423 U.S. at 302 (White, J., concurring).

28. Brown v. Maryland, 25 U.S. (12 Wheat.) at 441.

29. 423 U.S. at 279.

30. Conceivably, the Court was persuaded by the arguments of the California and Texas amici curiae brief on this issue. The importance of the question to states and localities may have been indicated by the submission of amicus curiae briefs by Kansas, Ohio, and Georgia, although these states did not argue that Low had been wrongly decided.

31. See, e.g., Hooven \& Allison Co. v. Evatt, 324 U.S. 652, 664-65 (1945); text at notes 4-6 supra. 
whether Michelin's tires had lost their status as "imports."32 Rather the Court focused upon the nature of the exaction at issue to ascertain whether it constituted a forbidden "impost" or "duty."

In exploring this question, the Court examined anew first the purpose and then the text of the import-export clause. The Court identified three principal concerns of the framers underlying the adoption of the constitutional prohibition against state taxation of imports. First, "the Federal Government must speak with one voice when regulating commercial relations with foreign governments, and tariffs, which might affect foreign relations, could not be implemented by the States consistently with that exclusive power." 33 Second, "import revenues were to be the major source of revenue of the Federal Government and should not be diverted to the States." 34 Third, "harmony among the States might be disturbed unless seaboard States, with their crucial ports of entry, were prohibited from levying taxes on citizens of other States by taxing goods merely flowing through their ports to the inland States not situated as favorably geographically."35

Viewing the tax in the light of these concerns, the Court could perceive nothing objectionable in a nondiscriminatory ad valorem property tax imposed on imports no longer in transit. It was "obvious" to the Court that such a tax could have "no impact whatsoever on the Federal Government's exclusive regulation of foreign commerce," because such a tax did not fall on imports "as such," and, therefore, could not be used "to create special protective tariffs or particular preferences for certain domestic goods," and could not be "applied selectively to encourage or discourage any importation in a manner inconsistent with federal regulation." ${ }^{36}$

The Court likewise found that imposition of a nondiscriminatory ad valorem property tax would not imperil the federal government's reliance upon imposts and duties as a major source of anticipated revenue. The Court's reasoning was in part definitional: because "nondiscriminatory ad valorem taxation is not in that category [of imposts and duties on imports], it deprives the Federal Government of nothing to which it is entitled." 37 In supporting its position that such taxes do not fall within the defined category, the Court again returned to the point that it regarded as most critical-the nondis-

32. 423 U.S. at 279.

33. 423 U.S. at 285 .

34. 423 U.S. at 285.

35. 423 U.S. at $285-86$.

36. 423 U.S. at 286.

37. 423 U.S. at $286-87$. 
criminatory character of the levies. Since a nondiscriminatory tax "cannot be selectively imposed and increased so as substantially to impair or prohibit importation," 38 such a tax has at most an "incidental effect" on federal import revenues "to the extent its economic burden may discourage purchase or importation of foreign goods." 39 According to the Court, prevention of this minor diminution of federal revenues was not "even remotely an objective of the Framers." 40

Nor, in the Court's view, would the imposition of nondiscriminatory ad valorem property taxes frustrate the third objective underlying the import-export clause: preserving harmony and maintaining the free flow of imported goods among the states by preventing some states from exploiting their favorable geographic location by taxing goods destined for other states. Here the Court was a bit more tentative. It acknowledged that "allowance of nondiscriminatory ad valorem property taxation may increase the cost of goods purchased by 'inland' consumers." 41 Furthermore, it may well have sensed, though it was not willing to say so explicitly, that nondiscriminatory property taxes imposed on goods stored by an importer-wholesaler like Michelin for distribution throughout the United States might in fact interfere with the free flow of imports among the states "by virtue of the cumulative impact of such taxes on the price of goods on their way to become part of a stock of goods for resale locally." 42 But, the Court reiterated, the tax "is the quid pro quo for benefits actually conferred by the taxing state,"43 so to deny the state the power to tax the property would compel it to provide either a subsidy to ultimate consumers or a competitive advantage to distributors and manufacturers dealing with imported goods. Moreover, the Court declared that the purposes of the import-export clause would be fully secured "merely by prohibiting the assessment of even nondiscriminatory property taxes on goods which are merely in transit through the State when the tax is assessed." 44 The clause

38. 423 U.S. at 287-88.

39. 423 U.S. at 287.

40. 423 U.S. at 287.

41. 423 U.S. at 288.

42. Dakin, The Protective Cloak of the Export-Import Clause: Immunity for the Goods or Immunity for the Process?, 19 LA. L. REv. 747, 766 (1959).

43. 423 U.S. at 289.

44. 423 U.S. at 290. The Court also noted that traditional commerce clause doctrine would likewise afford protection to the free flow of goods. 423 U.S. at 290 n.11. Indeed, the Court's gingerly treatment of this issue may have stemmed from its experience under the commerce clause. The Court had developed a doctrinal limitation on the constitutionality of nondiscriminatory state taxes in adopting the "multiple burdens" theory, see, e.g., Western Live Stock v. Bureau of Revenue, 303 U.S. 250, 258-60 (1938), which was most succinctly expressed in Justice Rut- 
would thus forbid a tax that threatened to impose a special burden upon imports, even though the levy did not explicitly discriminate against them.

Having demonstrated that the levy of a nondiscriminatory ad valorem property tax on imports would not, except to the limited extent noted, contravene the objectives of the import-export clause, the Court turned to the text of the clause itself. Conceding that the clause did not by its terms exclude nondiscriminatory taxes from its prohibition, the Court pointed out that it was equally clear that not every tax-but only "imposts or duties"-lay within its scope. As the Court noted, the constitutional grant of power to Congress "to lay and collect Taxes, Duties, Imposts, and Excises"45 supports a reading of the import-export clause as not forbidding every tax that falls in some measure on imports - a conclusion bolstered by Professor Crosskey's "persuasive demonstration"4 that the words "imposts" and "duties" were understood in 1787 to be exactions upon imports or importation as such. ${ }^{47}$ Although these considerations might have supported a definitive interpretation of the clause on the basis of its text, the Court was content to conclude that the language of the clause is sufficiently ambiguous to permit it to reject a construction that would not further the clause's objectives. ${ }^{48}$ Since these objectives were undisturbed by nondiscriminatory ad valorem property taxation, the text of the clause would not be construed as forbidding it.

It remained only for the Court to explain the error of its previous ways, to wit, Low v. Austin's ${ }^{49}$ misreading of Brown v. Maryland. Brown was precisely the type of case to which the import-export

ledge's concurring opinion in International Harvester Co. v. Department of Treasury, 322 U.S. 340, 358 (1944):

[T] he state may not impose certain taxes on interstate commerce, its incidents or instrumentalities, which are no more in amount or burden than it places on its local business, not because this of itself is discriminatory, cumulative or special or would violate due process, but because other states also may have the right constitutionally, apart from the commerce clause, to tax the same thing and either the actuality or the risk of their doing so makes the total burden cumulative, discriminatory or special.

See W. Hellerstein, supra note 3 , at 150-51 \& n.6.

45. U.S. CoNST. art. I, $\$ 8$, cl. 2.

46. 423 U.S. at $290-91$.

47. See 1 W. Crosskey, Politics and the Constitution in the History of THE UNITED STATES 296 (1953).

48. Chief Justice Marshall expressed similar views regarding the appropriate approach to interpreting the import-export clause: "When we are inquiring, whether a particular act is within this prohibition, the question is not, whether the State may so legislate as to so hurt itself, but whether the act is within the words and mischief of the prohibitory clause." Brown v. Maryland, 25 U.S. (12 Wheat.) 419 , 440 (1827).

49. 80 U.S. (13 Wall.) 29 (1872). 
clause was directed. It involved a fee levied by a coastal state on importers for a license they were required to obtain before selling within the state. Since the fee was equivalent to a discriminatory tax on the goods themselves, which fell squarely within the clause's prohibition, it could not stand. Although the Court in Brown devised the celebrated "original package" test as an evidentiary tool for determining when imported goods had lost their status as imports and thus the protection of the clause, it had indicated that the status of the goods was only one of the determinants of the validity of the tax. The other was the character of the tax: the clause prohibits only imposts and duties, not all exactions regardless of their nature. ${ }^{50}$ The Michelin Court had taken some pains to make this point, which it was now prepared to find "clearly implied" in Brown. ${ }^{51}$

In Low v. Austin," however, the Court had held, with "no

50. See 25 U.S. (12 Wheat.) at 437.

51. 423 U.S. at 298. It is not so clear that the Court in Brown regarded nondiscriminatory taxes as falling outside the proscription of the import-export clause. The Michelin Court found support for such a view in Chief Justice Marshall's comment that the exception in the import-export clause for imposts and duties "for the support of inspection laws, goes far in proving that the framers of the constitution classed taxes of a similar character with those imposed for the purposes of inspection, with duties on imports and exports, and supposed them to be prohibited." 423 U.S. at 297 (emphasis original) (quoting Brown v. Maryland, 25 U.S. (12 Wheat.) at 438). Reference to the entire passage from which the excerpt was quoted suggests that Marshall was simply making the point that a commodity does not lose its status as an import upon landing because inspection duties are generally levied after the goods are landed. See 423 U.S. at 276 . Indeed, the application of the inclusio unius est exclusio alterius principle to Marshall's observation that an inspection tax is a tax paid for services performed on land would suggest that other taxes imposed on imports to recover expenses incurred by the state-such as a property tax-are proscribed. See W. Hellerstein, supra note 6, at 108 n.51.

Chief Justice Marshall also stated that the critical feature of the Maryland tax was that it "intercept[ed] the import, as an import." 25 U.S. (12 Wheat.) at 443. The Michelin Court cited this as being indicative of the Brown Court's position that only those taxes levied exclusively on imports fall within the ban of the importexport clause. See 423 U.S. at 298. However, Chief Justice Marshall at this point was distinguishing between a tax on imports assessed before and one assessed after the imports are incorporated into the stream of commerce. He was not distinguishing between discriminatory and nondiscriminatory taxes. The other taxes Chief Justice Marshall mentioned, such as a tax for the use of a public auctioneer, can be viewed as levies not on imports or on the right to import but on activities collateral to the act of importing.

This is not to say that the Court's analysis of the policies underlying the importexport clause failed to justify its conclusion. The point is merely that the Court in Michelin may have overstated the support Brown offers for the appropriate result. Indeed, if the Court had been less anxious to find support in Brown, it might have acknowledged that its decision virtually displaced the "original package" concept altogether. See W. Hellerstein, supra note 6 , at $116-17$. One could argue that a discriminatory state tax on, for example, the retail sale of foreign-made televisions would, under the fundamental rationale of Michelin, violate the import-export clause though the goods previously were removed from their original packages. In any event, it would clearly violate the commerce clause. See id. at 117.

52. 80 U.S. (13 Wall.) 29 (1872). 
analysis,"53 that the state cannot levy a nondiscriminatory property tax on imported goods so long as they remain "imports." 54 According to Michelin, Low ignored "the language and objectives of the ImportExport Clause, and ... the limited nature of the holding in Brown,"55 and misperceived the scope of the "original package" doctrine. ${ }^{56}$ Low, it followed, had been incorrectly decided and was therefore overruled. ${ }^{57}$

Once the Court had formulated the governing doctrine, it had little difficulty upholding the levy at issue since Michelin did not contend that the tax was discriminatory on its face or as applied, and the Court summarily determined that the tires were not in transit..$^{58}$ In short, the Court in Michelin transfigured import-export clause analysis. By reexamining the underlying policies of the clause and the seminal decision construing it, the Court shifted the focus of the analysis away from the intricacies of the "original package" test to the more tractable question of the character of the tax..$^{69}$ And in so doing, the Court made it clear that the crux of the constitutional inquiry was whether the exaction at issue discriminated against or imposed a special burden upon imported goods.

\section{B. United States v. County of Fresno $0^{00}$}

In County of Fresno, as in Michelin, the Supreme Court rediscovered the "original intent" stitutional provision limiting state taxation and concluded that the nondiscriminatory levy in question lay outside the provision's scope. The supremacy clause, like the import-export clause, forbids state taxes directed specifically against the protected interest-the federal government in the one case, imports in the other. But, the Court now emphasizes, $M^{\prime} C u l l o c h v$. Maryland ${ }^{62}$ cannot be read as cutting a broad swath of tax immunity for federal instrumentalities any more than Brown v. Maryland can be read as creating such an immunity for imports.

In County of Fresno, the Supreme Court considered the constitutionality of a local tax on possessory interests in publicly owned, tax-

53. 423 U.S. at 294.

54. 80 U.S. (13 Wall.) at 34.

55. 423 U.S. at 298.

56. 423 U.S. at 282 .

57. 423 U.S. at 301 .

58. 423 U.S. at 302 .

59. See text at notes $32-44$ supra.

60. 97 S. Ct. 699 (1977).

61. 97 S. Ct. at 705 .

62. 17 U.S. (4 Wheat.) 316 (1819). See text at notes 78-80 infra. 
exempt realty as applied to federal employees living in federally owned houses. ${ }^{63}$ The taxpayers were employees of the United States Department of Agriculture's Forest Service. The Forest Service required the employees, who worked in national forests in Fresno and Tuolumne Counties, California, to live in the houses, located in the forests. The Forest Service deducted from its employees' salaries an amount corresponding to the fair rental value of similar housing in the private sector. ${ }^{64}$ The Forest Service employees, joined by the United States, brought suit against the two counties, contending that the taxes interfered with a federal function and discriminated against federal employees and, thus, offended the supremacy clause of the Constitution. ${ }^{65}$

The trial court sustained the taxpayers' claims on the ground that they had no taxable possessory interest under state law, ${ }^{66}$ but the intermediate appellate court reversed, holding that the taxpayers did in fact have such an interest in the federally owned houses. ${ }^{67}$ The appellate court went on to reject the contentions that the assessments interfered with a federal function and that they discriminated against the federal government or its employees. ${ }^{68}$

63. Local California taxing bodies are authorized to impose an annual use or property tax on possessory interests in publicly owned tax-exempt realty. All property in California not exempt by federal or state law is subject to such taxation. CAL. Rev. \& TAX. Code $\$ 201$ (West 1970). A " 'taxable possessory interest' means a possessory interest in nontaxable publicly owned real property, as such property is defined in section 104 of the Revenue and Taxation Code." CAL. ADMIN. CODE tit. 18, $\$ 21$ (b) (1975). Section 104 provides that real property includes "[ $t$ ]he possession of, claim to, ownership of, or right to the possession of land." CaL. REV. \& TAX CODE $§ 104$ (West 1970). CaL. ReV. \& TAX. CODE $§ 107$ (West 1970) states that "possessory interest" means "[p]ossession of, claim to, or right to the possession of land or improvements, except when coupled with ownership of the land or improvements in the same person."

64. The Forest Service viewed the occupancy of these houses as partial compensation for the services of its employees and made a deduction from an employee's salary for each two-week pay period in which the employee occupied such a house:

The Forest Service fixed the amount of the deduction by estimating the fair

rental value of a similar house in the private sector and then discounting that

figure to take account of the distance between the Forest Service house and

the nearest established community and the absence, if any, of any customary

amenities in or near the house. Adjustment was also made for the fact that

the Forest Service reserved the right to remove employees from their houses at

any time, to enter the houses with or without notice for inspection purposes, and

to use part or all of the houses for official purposes in emergency.

$97 \mathrm{~S}$. Ct. at 700-01 (footnote omitted).

65 . Both counties computed the amount of the employees' possessory interests based on the estimated fair rental values of the houses. Values were determined by considering essentially the same factors used by the Forest Service in setting fair rental amounts. $97 \mathrm{~S}$. Ct. at 701; see note 64 supra.

66. 50 Cal. App. 3d 633, 637, 123 Cal. Rptr. 548, 549 (1975).

67. $50 \mathrm{Cal}$. App. $3 \mathrm{~d}$ at $639-40,123 \mathrm{Cal}$. Rptr. at 551-52.

68. 50 Cal. App. 3d at 640-41, $123 \mathrm{Cal}$. Rptr. at 552. The court cited the Supreme Court's decisions in City of Detroit v. Murray Corp., 335 U.S. 489 (1958), United States v. Township of Muskegon, 355 U.S. 484 (1958), and United States 
The Supreme Court might well have affirmed the state court's decision in a brief per curiam opinion. It had squarely held in United States $v$. City of Detroit ${ }^{89}$ and United States v. Township of Muskegon ${ }^{70}$ that the supremacy clause was no bar to the imposition of a state tax upon a commercial lessee or user of federally owned property "in the same amount and to the same extent as though the lessee or user were the owner of such property."71 The Michigan court in those cases, like the California court here, had construed the state statute as imposing a tax on the lessee or user and not on the federal government, ${ }^{72}$ even though in both instances the tax was measured by the value of the federal government's property. Indeed, the California taxes seemed to rest on safer grounds than did those of Michigan, for the latter were measured by the fee value of the federal property leased or used by the taxpayer, whereas in County of Fresno the tax was measured only by the value of the lessee's possessory interest in such property. ${ }^{73}$ Furthermore, in Township of Muskegon, the Court refused to deny the states the power to tax merely because the property was being used by a government contractor in the performance of government contracts. ${ }^{74}$ Such a burden on a "federal function" was not of constitutional magnitude. Finally, since the Court had previously abandoned the "economic burden" test as a criterion for determining the scope of the federal government's immunity from state taxation, ${ }^{75}$ it was of no consequence that the federal government might in fact absorb the financial impact of the state levy, as it did in City of Detroit ${ }^{76}$ though not, apparently, in County of Fresno. ${ }^{77}$

The Court in County of Fresno did affirm, but not simply on the authority of those precedents. Instead, it returned to the source, $M^{\prime}$ Culloch v. Maryland, ${ }^{78}$ in an apparent effort to rationalize the

v. City of Detroit, 355 U.S. 466 (1958). The California Supreme Court denied review of the intermediate appellate court decision. See $97 \mathrm{~S}$. Ct. at 702.

69. 355 U.S. 466 (1958).

70. 355 U.S. 484 (1958).

71. 6 Мich. Stat. ANN. \$\$ 7.7(5), 7.7(6) (Cum. Supp. 1957), quoted in 355 U.S. $467-68$ n.1.

72. See United States v. City of Detroit, 345 Mich. 601, 605-12, 77 N.W.2d 79, 81-84 (1956); Township of Muskegon v. Continental Motors Corp., 346 Mich. 218, 222, 77 N.W.2d 799, 801 (1956).

73. See note 65 supra; text at note 71 supra.

74. 355 U.S. at $486-87$.

75. See United States v. City of Detroit, 355 U.S. at 472-73; Kern-Limerick, Inc. v. Scurlock, 347 U.S. 110 (1954); Alabama v. King \& Boozer, 314 U.S. 1 (1941).

76. 355 U.S. at 468.

77. See 97 S. Ct. at 705.

78. 17 U.S. (4 Wheat.) 316 (1819). 
analytical framework for determining the scope of the constitutional immunity of federal instrumentalities from state taxation. In $M^{\prime} C u l l o c h$, the Court confronted a Maryland tax levied' on notes issued by any bank not chartered by the state. ${ }^{79}$ No equivalent levy was imposed on Maryland banks. The only bank in Maryland actually fitting the statutory description was the Bank of the United States, created and incorporated by an act of Congress. In Chief Justice Marshall's landmark opinion, the Court held that Congress had constitutional authority to create the Bank and that Maryland's levy upon it was invalid under the supremacy clause:

The question is, in truth, a question of supremacy; and if the right of the States to tax the means employed by the general government be conceded, the declaration that the constitution, and the laws made in pursuance thereof, shall be the supreme law of the land, is empty and unmeaning declamation. ${ }^{80}$

In reexamining $M^{\prime} C$ ulloch, however, the Court found that the principles of federal. supremacy there elaborated were tempered by other considerations. The Court in County of Fresno adverts to the familiar language that the power to tax involves the power to destroy, but it emphasized those passages in $M^{\prime} C$ ulloch suggesting that in the proper circumstances the states may be permitted to exercise their tax power without fear of abuse. Specifically, the County of Fresno opinion stresses Marshall's rejection of the argument made by Maryland that the states should be trusted not to abuse their power to tax a federal function just as they must be trusted not to abuse their power to tax their own citizens:

The [M'Culloch] Court rejected the argument because the political check against abuse of the power to tax a State's constituents is absent when the state taxes only a federal function. A State's constituents can be relied on to vote out of office any legislature that imposes an abusively high tax on them. They cannot be relied upon to be similarly motivated when the tax is instead solely on a federal function. ${ }^{81}$

But the political check found lacking in $M^{\prime} C$ ulloch, where the tax was imposed solely on the Bank of the United States, "is present where the State imposes a nondiscriminatory tax only on its constituents or their artificially owned entities,"82 some of whom may be engaged in a federal function.

The Court in County of Fresno likewise underscored a further, related qualification of $M^{\prime} C$ ulloch: as Marshall himself acknowledged,

79. 17 U.S. ( 4 Wheat.) at 320-21.

80. 17 U.S. (4 Wheat.) at 433.

81. 97 S. Ct. at 702-03 (footnote omitted).

82. $97 \mathrm{~S}$. Ct. at 705 (footnote omitted). 
the decision did not "extend to a tax . . . imposed on the interest which the citizens of Maryland may hold in this institution [the bank], in common with other property of the same description throughout the State." 83

By stressing these two limiting elements of $M$ 'Culloch, the Court put a new face on this venerable case. Whatever its broad implications regarding the immunity that the federal government and its instrumentalities enjoy from state taxation, the case also stands for the limiting principle that the supremacy clause prohibits taxation of those who deal with the federal government only insofar as it discriminates against them because of their relationship with the federal government. Thus, the Court now emphasized, "McCulloch foresaw the unfairness in forcing a State to exempt private individuals with beneficial interests in federal property from taxes imposed on similar interests held by others in private property,"84 and it "expressly excluded from its rule a tax on interests which the citizens of Maryland may hold [in a federal instrumentality] in common with other property of the same description throughout the State." "85 The Court was therefore able to conclude in the County of Fresno case that the "rule" to be derived from its more recent decisions, which returned to the "original intent" of $M^{\prime} C u l l o c h$, was that "the economic burden on a federal function of a state tax imposed on those who deal with the Federal Government does not render the tax unconstitutional so long as the tax is imposed equally on the other similarly situated constituents of the State." 86

Having determined that the critical issue in the case was whether the California levy discriminated against the federal government or those associated with it (since there was no question that the "legal incidence" of the tax fell neither on the United States nor its property), the Court found that resolution followed easily. The levy did not tax federal employees living in federally owned houses differently from state employees living in state-owned houses. ${ }^{87}$ Nor did the tax single out lessees of tax-exempt property for discriminatory treatment by imposing on them a tax not borne by other lessees. Even though, as to private property, owners and not lessees are taxed, those who rent houses in the private sector would presumably

83. $97 \mathrm{~S}$. C. at 703 (quoting 17 U.S. (4 Wheat.) 316, 436 (1819) (emphasis original)).

84. $97 \mathrm{~S}$. Ct. at 705.

85. $97 \mathrm{~S}$. Ct. at 705 (bracketed material original) (quoting 17 U.S. (4 Wheat.) at 436 ).

86. $97 \mathrm{~S}$. Ct at 704-05 (footnote omitted).

87. 97 S. Ct. at $706 \mathrm{n.13}$. 
bear the economic burden of the tax imposed on their lessors. ${ }^{88}$ And the decisions in City of Detroit and Township of Muskegon, which had seemed controlling from the outset ${ }^{89}$ and upon which the Court ultimately relied, ${ }^{90}$ were not drained of force simply because they involved property employed for business rather than personal use-a difference the Court termed "inconsequential." 11 Rather, County of Fresno reaffirms and strengthens these decisions by supplying a doctrinal underpinning reaching into the bedrock of supremacy clause analysis.

In sustaining the California possessory interest tax, the Court in County of Fresno, as in Michelin, thus relied principally on the conclusion that the levy did not discriminate against or impose a special burden upon the constitutionally protected interest at issue. There are, however, important differences between the two decisions that should not be overlooked. First, the Court in County of Fresno explicitly adhered to the doctrine that the "states may not impose taxes directly on the Federal Government, nor may they impose taxes the legal incidence of which falls on the Federal Government,"92 regardless of the nondiscriminatory character of the levy. Thus the Court did not embrace the nondiscrimination principle in the context of state taxation of federal instrumentalities as fully as it did in the context of state taxation of imports. Yet M'Culloch no less than Brown would have justified a broader holding. For the M'Culloch opinion had stated that the decision did "not extend to a tax paid by the real property of the bank, in common with other real property within the State." ${ }^{93}$ On that assumption, it was not merely nondiscriminatory state taxation of the beneficial interests of private parties in federal property that fell outside the "original intent" of $M^{\prime} C$ Culloch; ${ }^{94}$ it was also nondiscriminatory state taxation of the federal property itself. Yet the Court was unwilling (in part, perhaps, because it was unnecessary) to extend its reasoning to such an exaction. ${ }^{95}$

The second, more critical, distinction relates to the actual effect of the tax. The Court's conclusion in County of Fresno that the state tax did not discriminate against the federal government is open to serious question, while there could have been no comparable objec-

88. $97 \mathrm{~S}$. Ct. at 706. Even on this assumption, it may still be argued, as did Justice Stevens in dissent, that the possessory interest levy nevertheless effectively discriminated against federal employees. See text at notes 96-98 infra.

89. See text at notes 69-77 supra.

90. $97 \mathrm{~S}$. Ct. at 706-07.

91. $97 \mathrm{~S}$. Ct. at 707.

92. $97 \mathrm{~S}$. Ct. at 703 (emphasis added).

93. 17 U.S. (4 Wheat.) at 436.

94. 97 S. Ct. at 704-05.

95. But see text preceding note 156 and at note 157 infra. 
tion to the Court's conclusion with regard to the imports at issue in Michelin. In his dissent to County of Fresno, the only dissenting vote in the three cases examined by this Article, Justice Stevens argued that the California possessory interest tax discriminated against the federal employees in two respects. First, he disagreed with the majority's assumption that the positions of the government employees and of the lessees of nonexempt property are equalized by the private landlords' passing their property tax burden onto their tenants. ${ }^{96}$ On the assumption that the private lessor's tax burden was passed through to his lessee, Justice Stevens noted that the fair market value of a lease would incorporate some amount representing the property tax burden. ${ }^{07}$ This fair market value is used by the federal government to determine the amount deducted from its employees' wages as rent for use of the government-owned houses, without any apparent adjustment to reflect the federal government's exemption from state property tax. Hence, the federal employees, in effect, bear a heavier tax burden than tenants of private lessors: they pay, like tenants of private lessors, a fair market rental that reflects, in part, the private lessor's tax burden; but unlike other lessees, they pay an additional tax to the state. ${ }^{98}$

Stevens also objected to the tax on the ground that it discriminated between lessees of publicly owned tax-exempt property and lessees of other exempt property who were not subject to the $\operatorname{tax}^{99}$ He pointed out that the possessory interest tax applies only to "publicly owned real property," not to all tax-exempt property. ${ }^{100}$

96. 97 S. Ct. at 708 (Stevens, J., dissenting).

97. The portion of the property tax passed on to the tenant might vary with market conditions. See 97 S. C. at 708.

98. Because the federal government is under no legal obligation to pay state taxes, it is in a position to receive higher net rents than those received by private landlords, whose gross rentals are reduced by their state tax liabilities. See $97 \mathrm{~S}$. Ct. at 708 n.4. Contrast the situation of the Forest Service lessees with that of the government's tenant in United States v. City of Detroit, 355 U.S. 466 (1958). In that case, the lease contract provided that a tenant could deduct from the rental charge any taxes paid on account of the leasehold property. 355 U.S. at 468 . Justice Stevens did not believe, however, that the ability of the federal government to shield its employees from the impact of taxes by making such a rent adjustment provided any justification for the levy: "I do not believe that the State's power can be exercised in a manner which requires the Federal Government to surrender its own tax exemption in order to protect its employees from a discriminatory tax." $97 \mathrm{~S}$. Ct. at 709 n.5.

Justice Stevens also observed that reimbursement would impose on the federal government not merely the economic burden represented by the value of taxes, see text at note 76 supra, but also "[t]he administrative burden of determining the correct amount of tax owed on each unique residence operating under myriad payment systems and due dates." 97 S. Ct. at 709 n.5.

99. 97 S. Ct. at 709. (1975)).

100. 97 S. Ct. at 709 (in part quoting CaL. ADMn. Code tit. 18, $\$ 21$ (b) 
It appeared to Justice Stevens that the only persons other than the federal employees liable for the tax were state employees living in state-owned houses. ${ }^{101}$ Yet, the State of California, and its political subdivisions, can readily adjust the rent charged to their tenantemployees to compensate for the tax. Consequently, in Stevens' view, "the tax may have a practical effect on the Federal Government and its employees which is different from its effect on the owners or users of any other tax-exempt property in the State."102

Justice Stevens was unable to persuade a single colleague to join him in these views. His dissent demonstrates, however, that discrimination is a malleable concept that will not necessarily reveal bright lines discernible to all observers. More specifically, his dissent identifies a major problem with the majority's approach to the factual issue of discrimination. If, as suggested in more detail below, ${ }^{103}$ the Supreme Court may be moving toward the view that the question of discrimination is the central issue in determining the constitutionality of the exercise of state tax power under the importexport, supremacy, and commerce clauses, the Court must determine how closely it will look at a state tax in ascertaining whether there is evidence of discrimination. The majority in County of Fresno focused primarily on the formal language of the statutory provisions to determine whether the levy discriminated against those who deal with the federal government. The alternative approach, exemplified by Stevens' dissent, is to consider the effect of the tax as implemented by the state. Thus, Stevens directed attention to the narrow base of the tax and to the possible disparate economic impact of the tax on federal and state employees. ${ }^{104}$ Ultimately, it is the nature of the inquiry that the Court undertakes that will determine the extent to which the nondiscrimination criterion will protect the interests the supremacy clause was designed to serve.

\section{Complete Auto Transit, Inc. v. Brady ${ }^{105}$}

In Complete Auto Transit, as in Michelin and County of Fresno,

101. 97 S. Ct. at 709. Presumably, municipal employees living in municipally owned houses would also be subject to the tax, at least to the extent that such municipally owned houses were themselves tax exempt.

102. $97 \mathrm{~S} . \mathrm{Ct}$. at 709.

103. See text preceding note 135 infra and accompanying and following note 136 infra.

104. The restricted application of the tax-imposing liability only for users of publicly owned real property-appears on the face of the statute. The examination of the economic impact of the tax-including, most critically, the recognition that the state may well adjust the rents charged its own employees-evidences a more detailed analysis focused on actual effects.

105. $97 \mathrm{~S}$. Ct. 1076 (1977). The following discussion draws freely from my article, supra note 3. 
the Court reexamined old doctrine and concluded that the purposes of a constitutional restraint on state taxation would not be furthered by proscribing the nondiscriminatory levy at issue. The decision indicates that the commerce clause, like the import-export clause and the supremacy clause, is to be viewed as restraining the exercise of state tax power without creating a broad zone of tax immunity for the constitutionally protected interest.

The case involved a Mississippi tax "for the privilege of engaging or continuing in business or doing business within this state,"100 levied upon every person operating a "transportation business for the transportation of persons or property for compensation or hire between points within this State."107 The tax was measured by the gross receipts from the business. ${ }^{108}$ The taxpayer's Mississippi operations consisted of hauling motor vehicles to dealers in the state from a railroad depot in Jackson, Mississippi, where they had been shipped from out-of-state assembly plants. ${ }^{109}$ The vehicles were normally loaded on Complete's trucks and delivered to Mississippi dealers within forty-eight hours after arrival in Jackson. ${ }^{110}$ Complete alleged that its transportation services were an integral part of an interstate movement so that the imposition of the tax violated the commerce clause. ${ }^{111}$ Its claim was predicated solely on the fact that the levy was imposed on the "privilege of doing interstate business," "112 which the Court had long held to be immune from state taxation under the commerce clause. ${ }^{113}$ In light of the assumption made both by the Mississippi courts and the Supreme Court that the transportation services under consideration constituted interstate rather than intrastate commerce, ${ }^{114}$ the taxpayer's contention-at least on its face-did not lack force. Yet the true nature of the issue confronting the Supreme Court after the state courts sustained the assessments cannot be fully appreciated without some essential background.

One of the fundamentals of commerce clause doctrine was that an enterprise doing exclusively interstate business could not constitutionally be subjected to a state tax imposed on the privilege of doing

106. Miss. Code ANN. $\$ 27-65-13(2)$ (1972) quoted in 97 S. Ct. at 1077.

107. Miss. Code ANN. $\S 27-65-19(2)$ (1972) quoted in 97 S. Ct. at 1077.

108. Miss. Code ANN. $\S 27-65-19(2)$ (1972) quoted in 97 S. Ct. at 1077.

109. $97 \mathrm{~S}$. Ct. at 1077 .

110. 97 S. Ct. at 1077.

111. 97 S. Ct. at 1078.

112. Brief for Appellant at 20-27.

113. See W. Hellerstein, supra note 3, at 177-80.

114. See 9.7 S. Ct. at 1077 n.4. 
business in that state. ${ }^{115}$ The principle grew out of a logical-but not necessary ${ }^{116}$ - inference the Court drew from the proposition that the commerce clause precluded a state from preventing an outof-state corporation from engaging in interstate business within its borders. ${ }^{117}$ Thus, the Court long ago held that a state cannot impose a tax or fee upon a foreign corporation as a condition to commencing business in the state ${ }^{118}$ and then extended the principle to forbid a tax on the privilege of doing business, as applied to a foreign corporation doing exclusively interstate business in the taxing state, even though the tax was not levied as a condition to commencing business. ${ }^{119}$ It made no difference that both foreign and domestic corporations and both interstate and intrastate business were taxed on a nondiscriminatory basis. ${ }^{120}$

Over the years, however, as judicial attitudes toward state tax power became more generous, significant inroads were made on the doctrine that the privilege of doing interstate business was immune from state taxation. By identifying "local incidents" of interstate business, which the states could properly tax, the Court chipped away at the scope of the privilege. ${ }^{121}$ Without explicitly abandoning the privilege concept, the Court developed the multiple taxation doctrine that undermined the basis for the tax immunity ${ }^{122}$ and led to distinctions between cases that became increasingly gossamer. ${ }^{123}$ In addition, the Court appeared to sanction state taxation of exclusively interstate business in several decisions summarily affirming state court rulings. ${ }^{124}$

115. See Memphis Steam Laundry Cleaner, Inc. v. Stone, 342 U.S. 389, 393 (1952); General Trading Co. v. State Tax Commn., 322 U.S. 335, 338 (1944); Atlantic \& Pac. Tel. Co. v. Philadelphia, 190 U.S. 160, 162 (1903).

116. See J. Hellerstein, State Franchise Taxation of Interstate Business, 4 TAX L. REv. 95,99 (1948).

117. Pensacola Tel. Co. v. Western Union Tel. Co., 96 U.S. 1, 12-13 (1877); cf. Allenberg Cotton Co. v. Pittman, 419 U.S. 20, 37 (1974) (Rehnquist, J., dissenting) (notes cases holding that a business organized in one state that is engaged in interstate commerce cannot be compelled by a second state to qualify under its requirements to carry on business).

118. See Western Union Tel. Co. v. Kansas ex rel. Coleman, 215 U.S. 1, 4748 (1910); Leloup v. Port of Mobile, 127 U.S. 640, 645 (1888).

119. Alpha Portland Cement Co. v. Massachusetts, 268 U.S. 203, 217 (1925); Cheney Bros. v. Massachusetts, 246 U.S. 147, 153-54 (1918). See J. Hellerstein, supra note 116, at 99 .

120. See sources cited in note 11.9 supra.

121. See, e.g., Memphis Natural Gas Co. v. Stone, 335 U.S. 80 (1948); Coverdale y. Arkansas-Louisiana Pipe Line Co., 303 U.S. 604 (1938).

122. J. Hellerstein, supra note 116, at 101-02 \& n.27.

123. Compare, e.g., Michigan-Wisconsin Pipe Line Co. v. Calvert, 347 U.S. 157 (1954), with Interstate Oil Pipe Line Co. v. Stone, 337 U.S. 662 (1949).

124. See, e.g., Field Enterprises, Inc. v. State, 47 Wash. 2d 852, 289 P.2d 1010 
These developments reached their climax in Northwestern States Portland Cement Co. v. Minnesota ${ }^{125}$ and Colonial Pipeline, Inc. v. Traigle. ${ }^{126}$ In Northwestern, the Court held that the commerce clause did not preclude a state from imposing a fairly apportioned, nondiscriminatory net income tax upon an out-of-state corporation engaged exclusively in interstate commerce in the taxing state. At the same time, however, the Court reaffirmed its decision in Spector Motor Service, Inc. v. O'Connor, ${ }^{127}$ where it had invalidated a Connecticut tax similar in virtually every respect to the tax at issue in Northwestern except that it was levied on the privilege of doing business in the state. The distinction the Court perceived between the two cases was that the formal subject of the $\operatorname{tax}^{128}$ in Northwestern was the corporation's net income, whereas in Spector it was the privilege of doing business. Since the measure of the levies at issue in both Spector and Northwestern was the corporation's net income, the immunity that exclusively interstate commerce enjoyed from state taxation apparently depended on whether the legislative draftsmen called the tax by the right name.

In Colonial, the Court again demonstrated that the protection afforded the interstate enterprise by the tax-immune privilege of doing business was feeble at best. The taxpayer, an interstate pipeline conducting an exclusively interstate business in the state, was held taxable for the privilege of doing business in corporate form, which the Court found distinguishable from a forbidden levy on the privilege of doing business. The case presented a particularly dramatic illustration of the illusory character of the privilege concept

(1955), affd. per curiam, 352 U.S. 806 (1956); West Pub. Co. v. McColgan, 28 Cal. 2d 705, 166 P.2d 861, affd. per curiam, 328 U.S. 823 (1946).

125. 358 U.S. 450 (1959).

126. 421 U.S. 100 (1975).

127. 340 U.S. 602 (1951). The Northwestern Court cited Spector in stating that it was "beyond dispute that a State may not lay a tax on the 'privilege' of engaging in interstate commerce." 358 U.S. at 458.

128. The subject is the legal incidence of a tax; it is the thing or event upon which the power to tax is based. The measure of a tax is the yardstick to which the rate is applied. Subject and measure may be distinct, as in a privilege tax, where the subject is the privilege and the measure is, for example, income; or subject and measure may coincide, as in an income tax, where the income is both the subject upon which the tax power is predicated and the basis upon which the amount due is calculated. It is the subject of a tax which has constitutional significance. The measure, at least in theory, has not presented constitutional questions. See, e.g., Atlantic Ref. Co. v. Virginia, 302 U.S. 22, 26-27 (1937); Kansas City, F. S. \& M. Ry. v. Botkin, 240 U.S. 227, 233 (1916). But the Court has occasionally attributed constitutional import to the measure of a tax by obscuring the distinction between subject and measure. See, e.g., Gwin, White \& Prince, Inc. v. Henneford, 305 U.S. 434, 438-40 (1939); New Jersey Bell Tel. Co. v. State Bd. of Taxes \& Assessments, 280 U.S. $338,348-49$ (1930). 
because the same taxpayer had successfully resisted imposition of an earlier version of virtually the identical levy that had been imposed on the privilege of doing business rather than the doing of business in corporate form. With a minimum of wordsmithing the state legislature was able to deprive the taxpayer of its tax immunity, thereby giving credence to Justice Blackmun's remark that the Court was putting its imprimatur upon "taxation by semantics."129

Thus when the Court in Complete Auto Transit was "[o]nce again . . . presented with " "the perennial problem of the validity of a state tax for the privilege of carrying on, within a state, certain activities" relating to a corporation's operation of an interstate business," "130 the- tax-immune privilege of doing interstate business was at most a narrowly confined restraint on the exercise of state power. And it therefore came as no surprise when the Supreme Court upheld the application of Mississippi's tax to the receipts from Complete's transportation services. But this time the Court did not simply seize upon yet another "local incident" in some way distinguishable from the privilege of doing interstate business as a predicate for sustaining the tax. Instead, it overruled Spector; flatly repudiated the privilege concept altogether, along with the philosophy underlying it; declared that the commerce clause is no bar to a nondiscriminatory, fairly apportioned levy imposed upon a taxpayer carrying on an interstate business in the taxing state; and made it clear that the clause has not created an irreducible zone of tax immunity unrelated to its purposes.

The Court traced the modern origin of the privilege doctrine to Justice Frankfurter's opinion in Freeman v. Hewit, ${ }^{131}$ which reflected. "an underlying philosophy that interstate commerce should enjoy a sort of 'free trade' immunity from state taxation." ${ }^{132}$ It described the gradual erosion of the doctrine in face of the emerging principle that a tax would be sustained against a commerce clause challenge so long as it is "applied to an activity with a substantial nexus with the taxing state, is fairly apportioned, does not discriminate against interstate commerce, and is fairly related to services provided by the State."133 And it concluded:

Not only has the philosophy underlying the rule been rejected, but the rule itself has been stripped of any practical significance.

129. 421 U.S. at 115 (Blackmun, J., concurring).

130. 97 S. Ct. at 1076 (quoting Colonial Pipeline, Inc. v. Traigle, 421 U.S. 100, 101 (1975), quoting Memphis Natural Gas Co. v. Stone, 335 U.S. 80, 85 (1948)).

131. 329 U.S. 249 (1946).

132. $97 \mathrm{~S}$. Ct. at 1078 (footnote omitted).

133. $97 \mathrm{~S}$. Ct. at 1079. See $97 \mathrm{~S}$. Ct. at 1079-83; see also text at notes 11529 supra. 
If Mississippi had called its tax one on "net income" or on the "going concern value" of appellant's business, the Spector rule could not invalidate it. There is no economic consequence that follows necessarily from the use of the particular words, "privilege of doing business," and a focus on that formalism merely obscures the question whether the tax produces a forbidden effect. Simply put, the Spector rule does not address the problems with which the Commerce Clause is concerned. Accordingly, we now reject the rule of Spector Motor Service, Inc. v. O'Connor . . . that a state tax on the "privilege of doing business" is per se unconstitutional when it is applied to interstate commerce, and that case is overruled. ${ }^{134}$

As in Michelin and County of Fresno, once the applicable principles were established, decision followed easily. Since the only objection to the application of Mississippi's tax to Complete's activities in the state was that it was imposed on the privilege of doing interstate business, the tax had, with the overruling of Spector, become unobjectionable. In sum, the Court once again reevaluated prior doctrine and announced a principle of constitutional adjudication designed to safeguard the protected interest without creating a broad area of tax immunity.

\section{TOWARD a MORE UNIFIED APPROACH to Constitutional Adjudication of State Tax Questions}

In three decisions rendered in the space of little over a year, the Supreme Court has taken a more unified and systematic approach than in the past to the interpretation of constitutional limitations on state taxation bearing on the allocation of powers between the state and national governments. In each case, a different constitutional restraint was the basis of a challenge to a state tax levy. In each case, the Supreme Court rejected the challenge, and, in so doing, either repudiated or limited prior doctrine that had once been used to carve out a broad zone of tax immunity for interests protected by the constitutional provision in question. And, in each case, the Court's opinion can fairly be read as stressing a common doctrinal theme: so long as the state tax does not discriminate against or impose special burdens upon the constitutionally protected interest, the tax will be sustained. The protection that the import-export, commerce, and supremacy clauses accord to imports, commerce, and the federal government provides immunity from state taxation only to the extent necessary to avoid discrimination against or the imposition of special burdens upon the protected interest.

134. $97 \mathrm{~S}$. Ct. at 1083-84 (footnote omitted). 
In Michelin, the Court disentangled itself from the thorny problem of locating imported goods in time and space in the context of their intended use to determine whether they had retained their distinctive character as imports. Instead, the Court's opinion makes it clear that the central question in such cases is whether the exaction at issue discriminates against imported goods on the basis of their foreign origin. ${ }^{135}$ In Complete Auto Transit, the Court similarly reformulated the framework for analyzing the constitutionality of a state tax on an interstate business in cases arising under the commerce clause. No longer will courts be concerned with the question whether a tax is imposed on the privilege of doing interstate business. Instead, the Court's opinion makes it clear that the central question in such cases is whether the tax is nondiscriminatory. ${ }^{136}$ The County of Fresno Court did not explicitly restructure the decisionmaking framework for determining the constitutionality of a state tax on a federal instrumentality in cases arising under the supremacy clause, but it did place renewed emphasis upon one aspect of the constitutional analysis. On the assumption that the levy is not imposed directly on the United States and that its legal incidence does not fall on the federal government, the Court's opinion makes it clear that the central question in such cases is whether the tax discriminates against the federal government or its instrumentalities and those who deal with them.

It is important to recognize, of course, that the Court did not exalt the nondiscrimination principle into the exclusive criterion by which the constitutionality of state taxes would be determined under the three clauses at issue. Michelin qualifies the nondiscrimination doctrine by disapproving even nondiscriminatory taxes on goods in transit, for such a tax would threaten to saddle imports with burdens not necessarily borne by domestic products. ${ }^{137}$ Complete Auto Transit does not disturb the requirements that the taxed enterprise have some nexus with the taxing state and that the tax be fairly apportioned to the activities carried on there. ${ }^{138}$ Finally, County of Fresno reasserted the important qualification of the nondiscrimina-

135. This is not to suggest that discrimination is the exclusive criterion by which the constitutionality of such a tax will be determined under the import-export clause. See text at notes 44 supra and 137 infra.

136. This is not to suggest that discrimination is the exclusive criterion by which the constitutionality of such a tax will be determined under the commerce clause. See text at notes 133 supra and 138 infra.

137. See text at note 44 supra. The doctrinal basis for proscription of a nondiscriminatory tax on imported goods is obscure. See W. Hellerstein, supra note 6, at 116.

138. See text at note 133 supra. 
tion doctrine that a tax whose legal incidence falls on the United States or its property is, ipso facto, invalid. ${ }^{139}$

These qualifications notwithstanding, the import of these cases is to make it clear that the relevant constitutional provisions-the import-export clause, the commerce clause, and the supremacy clause-do not completely shelter certain property or activities from state taxation, as it was once thought they did. To be sure, since state taxation of imports, of interstate commerce, or of those who deal with the federal government may trench on the domain of powers that are allocated to the national government under the clauses in question, the interests that these clauses were designed to protect are still accorded constitutional solicitude. But the level of protection has been reduced from an impregnable zone of immunity to essentially a guarantee of nondiscriminatory treatment.

The Court's emphasis upon the nondiscrimination principle as a basis for adjudicating controversies over the exercise of state tax power under the import-export, commerce, and supremacy clauses raises the possibility that these cases share an additional element of doctrinal consistency. It may be suggested that the Court, in viewing the clauses under consideration as designed principally to shield certain national interests from abusive state legislation, is manifesting an increased willingness to rely upon the restraining influence of the democratic political process to achieve this purpose. In County of Fresno the Court explicitly adverted to this notion that the political process can be relied upon to guard against abusive state taxation of the protected federal interests. ${ }^{140}$ This theory, as the Court observed in County of Fresno, is not a novel idea; ${ }^{\mathbf{1 4 1}}$ it was clearly anticipated by Chief Justice Marshall in M'Culloch $v$. Maryland:

The only security against the abuse of [the] power [to tax] is found in the structure of the government itself. In imposing a tax the legislature acts upon its constituents. This is, in general, a sufficient security against erroneous and oppressive taxation.

The people of a state, therefore, give to their government a right of taxing themselves and their property, and as the exigencies-of government cannot be limited, they prescribe no limits to the exercise of this right, resting confidently on the interest of the legislator, and on the influence of the constituent over their representatives, to guard them against its abuse. But the means employed by the government of the Union have no such security . . . .142

Indeed, Marshall seemed prepared to carry the theory further than

139. $97 \mathrm{~S}$. Ct. at 703.

140. 97 S. Ct. $669,704-05 \&$ n.11.

141. See 97 S. Ct. at 702-03.

142. 17 U.S. (4 Wheat.) at 428 (emphasis original). 
the Court has ever gone. His statement that the $M^{\prime} C$ ulloch decision does not apply to a tax on the national bank's real property, or to a tax on the interests of its investors levied "in common with other property of the same description throughout the state,"143 intimates that, where the tax is nondiscriminatory such that the federal interest enjoys the full measure of protection inhering in the political process, the tax does not violate the supremacy clause. ${ }^{144}$ Although the Court has repeatedly held that a tax is invalid if its legal incidence falls on the federal government, whether or not the tax is discriminatory, the County of Fresno case may presage the Court's willingness to reopen this question. ${ }^{145}$

Recognition of the political check as a mechanism for protecting federal interests has been clearest in supremacy clause analysis. ${ }^{146}$

143. 17 U.S. (4 Wheat.) at 436.

144. The Court's reliance upon a "political check" as a safeguard against the abuse of state tax power helps clarify the significance of Justice Stevens' dispute with the majority in County of Fresno. Such reliance is premised on the theory that a tax imposed on those engaged in the federally protected activity will not exceed the bounds of reasonableness if legislators must impose the same burden on their own constituents. But this "political check" induces restraint only if the onus of the $\operatorname{tax}$ borne by nonlocal interests is likewise borne by a substantial segment of the electorate. Examining the "actual effects" of the tax, as Justice Stevens did in his County of Fresno dissent, represents an effort to evaluate the strength of the political restraint. It will be recalled that he found that the burden of California's possessory interest tax was unlikely to fall on any analogous group to which the state government was responsive or with respect to which it could not make some compensating adjustment. Thus, there was, in Justice Stevens' view, no assurance that the federal employees would be protected by any local political restraint.

In contrast, the majority, while invoking the principle that the existence of a political check upon the exercise of state tax power will safeguard the constitutionally protected interest, $97 \mathrm{~S}$. Ct. at 704-05, nevertheless was content to rely primarily upon the formal equality provided by the state's statutory scheme without critically examining the actual impact of the levy upon persons to whom the legislature is politically accountable. If the Court subscribes to the view that, left unchecked, the states cannot be trusted to subordinate local to national interests, and if it is looking to the restraints inherent in the political process as furnishing the necessary check, it is incumbent upon the Court to verify that the political restraint is not a spurious one.

145. See $\S$ III infra.

146. The Court has also adverted to the inherent protection afforded by the political process in striking down discriminatory state taxation under the privileges and immunities clause of article IV:

The Privileges and Immunities Clause, by making noncitizenship or nonresidence an improper basis for locating a special burden, implicates not only the individual's right to nondiscriminatory treatment but also, perhaps more so, the not represented in the taxing State's legislative halls, ... judicial acquiescence in taxation schemes that burden them particularly would remit them to such redress as they could secure through their own State. . . .

Austin v. New Hampshire, 420 U.S. 656, 662 (1975) (emphasis added). Cf. Allied Stores, Inc. v. Bowers, 358 U.S. 522, 533 (1959) (Brennan, J., concurring) (state tax discriminating in favor of out-of-state business is valid under the equal protection clause; the clause need not be applied mechanically to give residents the same protection afforded nonresidents with respect to state taxing schemes). 
The theory might, however, play some role in the analysis of state tax legislation under the commerce and import-export clauses in light of the increased weight the Court has placed upon the nondiscrimination principle. It has been observed that it is

relevant to inquire whether [a] tax is subject to local political check and is comparable in its effect to the taxes imposed by the state on other business. If the incidence of a tax falls to a significant degree on persons to whom the legislature is politically responsible, i.e., local voters, it is possible that the burden of the tax and hence perhaps its deleterious effect on interstate commerce will be less than might otherwise be the case. ${ }^{147}$

And the Court itself has remarked in upholding state regulatory legislation over commerce clause objections that "[t]he fact that [the regulations] affect alike shippers in interstate and intrastate commerce in large number within as well as without the state is a safeguard against their abuse."148 Conceivably the Court will pay closer attention to the question whether state tax legislation is subject to an effective local political check in determining whether the tax is discriminatory under the commerce clause. ${ }^{\mathbf{1 4 0}}$

In view of the Court's reasoning in Michelin, it might likewise be suggested that it is relevant to inquire whether the levy at issue is subject to a local political check for purposes of analysis under the import-export clause. The Court noted that one of the principal concerns of the framers in adopting the import-export clause was to allay fears that coastal states would abuse their position to the detriment of their sister states and national policy by singling out imports for discriminatory taxation. ${ }^{150}$ To the extent that a tax is nondiscriminatory in its impact and falls equally on persons to whom the state legislature is politically responsible, the restraints inherent in the democratic process will tend to safeguard the constitutionally protected interest from abusive state taxation. ${ }^{151}$

147. Developments in the Law-Federal Limitations on State Taxation of Interstate Business, 75 HARv. L. REv. 953, 957 (1962) [hereinafter cited as Developments]. (1938).

148. South Carolina State Highway Dept. v. Barnwell Bros., 303 U.S. 161, 187

149. It should be noted, however, that

the degree of political influence possessed by those bearing the tax will in many

cases be only conjectural; the presence of political controls may not assure a

tax's compatibility with the notion of an open economy; and even if such con-

trols are clearly absent, unconstitutionality is not a necessary inference, since the

tax burden may for other reasons not impede free trade.

Developments, supra note 147, at 957-58.

150. Michelin Tire Corp. v. Wages, 423 U.S. at 283-86, 289-90.

151. It should be pointed out, however, that, although Chief Justice Marshall indicated in Brown that the fears to which the Court later adverted in Michelin represented one of the motivations behind the adoption of the import-export clause, 25 U.S. (12 Wheat.) at 439 , he did not draw the inference, as he had in $M^{\prime} C u l l o c h$, that 
Needless to say, there are obvious dangers in attempting, as above, to generalize broadly from a mere triad of cases. Nevertheless, it is significant that, in all three cases, the Court, with virtual unanimity, ${ }^{152}$ was willing to look past recent precedent and to reacquaint itself with the underlying purposes of the constitutional prohibitions with which it was dealing. Thus, in returning to the fundamental objectives of the import-export and supremacy clauses, the Court drew sustenance for its constitutional analysis from its landmark decisions in Brown v. Maryland and M'Culloch v. Maryland. Moreover, the Court's willingness to discard prior doctrine and to restructure its analysis of problems that have confronted it (and will no doubt continue to confront it) for years is also a telling indication that a major shift may be taking place in the Court's attitude toward those limitations on state tax power involved in the three recent cases under consideration here. While neither Low v. Austin nor Spector Motor Service, Inc. v. O'Connor seriously inhibited the exercise of state tax power, they were monuments to a certain way of thinking about the constitutional limitations on state taxation, and their overruling should be viewed in that light. And it is also noteworthy that the Court issued its opinions in these three cases through different spokesmen-Justices Brennan, White, and Blackmun-who span the Court's ideological spectrum on many other issues.

It is, of course, quite conceivable that the parallels between these three cases are simply coincidental in view of their concern with distinct constitutional limitations embodying different purposes. Furthermore, the suggested interpretation of the Court's decisions is by no means the only reading they may fairly be given. Michelin, to be sure, marks a fundamental change in the Court's approach to the constitutional limitations on the taxation of imports, replacing the "original package" concept with nondiscrimination as the central criterion for determining a levy's validity under the import-export clause. But County of Fresno may be read as simply a reaffirmation of City of Detroit and Township of Muskegon coupled with an explicit refusal to abandon the "legal incidence" test as a basis for

protection from the dangers of abusive state taxation might be found in the political restraints imposed on state legislation by those to whom the legislature was politically responsible. Rather, he concluded that the framers thought the power to levy imposts or duties on imports was one "which no State ought to exercise." 25 U.S. (12 Wheat.) at 440.

152. The single dissent in the three cases was Justice Stevens' opinion in County of Fresno. See text preceding note 96 supra and text at notes 96-104 supra. Justice White separately concurred in the Michelin decision. In a brief statement, he expressed the view that it was unnecessary to overrule Low v. Austin since the tires had lost their character as imports and thus were taxable under prior doctrine. 423 U.S. at 302. 
determining the validity of a state tax upon a federal instrumentality under the supremacy clause. And Complete Auto Transit may be viewed as no more than the doctrinal recognition of what was plain to any observer-that the commerce clause did not bar the states from imposing a nondiscriminatory, fairly apportioned tax upon an exclusively interstate business with a sufficient nexus with the state. Nevertheless, the consistency in the reasoning, tone, and results in these three cases provides a basis for suggesting that the Court is in fact adopting a more coherent approach to the restraints imposed on state tax power by the import-export, commerce, and supremacy clauses.

Finally, it should be recognized that, even if the Court is in the process of developing a more systematic approach to state taxation under these three clauses, the results in subsequent cases involving such issues will not necessarily be substantially different than if they had been decided under prior doctrine. Indeed, it is quite likely that the result in both Michelin and Complete Auto Transit would have been the same under the "original package" and "privilege" doctrines. ${ }^{153}$ Moreover, the propounding of new doctrine does not remove uncertainty as to how cases will be decided under it. Justice Stevens' opinion in County of Fresno demonstrates that the factual determination whether a particular tax discriminates against or imposes a special burden upon the protected interest is subject to varying interpretations, although, inasmuch as his was the lone dissent, one might suspect that this problem will not trouble the Court in the near future. In addition, the decisions leave open certain issues where the nondiscrimination doctrine is subject to qualification. ${ }^{154}$ Nonetheless, the Court's apparent embrace of the nondiscrimination principle as a critical-if not the critical-touchstone for determining the constitutionality of a state tax under the importexport, supremacy, and commerce clauses is a noteworthy development.

\section{A Postscript: State Taxation of the FEDERAL GovernMENT}

The most striking qualification of the nondiscrimination doctrine reflected in the three cases under consideration is contained in County of Fresno: a state tax whose legal incidence falls on the

153. The decisions by the state courts, which were affirmed on other grounds by the Supreme Court, were based on the Court's prior doctrines. See Michelin Tire Corp. v. Wages, 233 Ga. 712, 214 S.E.2d 349 (1975); Complete Auto Transit, Inc. v. Brady, 330 So. 2d 268 (Miss. 1976).

154. See text at notes 137-39 supra. 
United States or its property is barred by the supremacy clause regardless of whether it discriminates against or imposes a special burden upon the federal government. On this point the Court continues to adhere to the type of rule that it discredited in Michelin and Complete Auto Transit and, indeed, to some extent in County of Fresno itself. Yet it is conceivable that we have not heard the last from the Court on this question. In Colonial Pipeline, it will be recalled, ${ }^{155}$ the Court went to some lengths to assert its belief in the continuing vitality of the tax-immune privilege of doing interstate business while rendering a decision that effectively dealt the privilege its coup de grace. A mere two years later, the Court interred the privilege in Complete Auto Transit and cleanly broke with the past. The analogy between Colonial and Fresno, it may be argued, is not wholly farfetched. The Court, although affirming prior doctrine regarding the immunity of the United States from state taxation, nevertheless renders a decision and elaborates principles intimating that there may be little more than the weight of unexamined precedent behind the notion that the property of the United States itself is exempt from a nondiscriminatory tax. Indeed, if the Court had not quoted $M^{\prime} C$ ulloch with such studied selectivity, it would have been hard pressed to confine its reasoning to nondiscriminatory levies imposed on interests held by private citizens in federal property. As noted earlier, M'Culloch itself stated that the opinion did "not extend to a tax paid by the real property of the bank, in common with other real property within the state,"156 which indicates that the $M^{\prime}$ Culloch Court never intended to immunize the federal government's real property from nondiscriminatory state taxation. ${ }^{157}$

Nevertheless, while the federal government's immunity from state taxation may originally have been conceived as limited to discriminatory levies, ${ }^{158}$ there is more than the weight of unexamined precedent to explain and, indeed, justify continued adherence to existing doctrine. One need only contemplate the prospect of

155. See text preceding note 129 supra.

156. 17 U.S. (4 Wheat.) at 436.

157. At another point in his opinion, Marshall dismissed the contention that a distinction can be made under the supremacy clause between real property and other subjects of taxation. 17 U.S. (4 Wheat.) at 432-33. Thus, it would seem that if "the mail," "the mint," "patent rights," "the papers of the custom house," and the "judicial process" are encompassed within the definition of some state tax of general applicability, the holding in $M^{\prime}$ Culloch would not extend to such an exaction.

158. Cf. Justice Marshall's comment in his dissent in First Agr. Natl. Bank v. State Tax Commn., 392 U.S. 339, 350 (1968): "One could, and perhaps should, read $M^{\prime}$ Culloch and Osborn [v. Bank of United States, 22 U.S. (9 Wheat.) 738 (1824)] simply for the principle that the Constitution prohibits a State from taxing discriminatorily a federally established instrumentality." 
abandoning the rule that a nondiscriminatory tax on the United States or its property is barred by the supremacy clause to appreciate its virtues. What, for example, are state tax authorities to do in the event that the federal government falls behind in its tax payments? Traditional remedies available to enforce collection of delinquent taxes-distraint and sale-hardly seem appropriate. And how, for example, would a county assessor determine the value of a naval installation for the purposes of a nondiscriminatory ad valorem property tax? Traditional valuation techniques are unlikely to yield satisfactory results. ${ }^{159}$ Such horribles may well be imaginary, but their specter indicates that there are cogent policy reasons for the immunity that the federal government continues to enjoy under the County of Fresno holding. ${ }^{100}$ Although the expanded role of the nondiscrimination principle in the analysis of the immunity of federal instrumentalities from state taxation may be a healthly development, the $M^{\prime}$ 'Culloch dictum concerning nondiscriminatory taxes on federal property may be best left unexhumed.

\section{ConClusion}

Three recent opinions of the Supreme Court dealing with different constitutional restraints on state taxation have approached the

159. Of the three basic approaches to the valuation of real estate-market data (based on comparable sales), capitalized net income, and reproduction cost new less depreciation-only the cost method would appear to be applicable. See generally AMERICAN Institute of Real Estate Appraisers, The Appraisal of Real Estate 64-72 (6th ed. 1973). And it is highly questionable whether the cost of a government facility bears any relationship to its fair market value, which is, at least in principle, the valuation standard underlying state property tax systems. See Note, The Road to Uniformity in Real Estate Taxation: Valuation and Appeal, 124 U. PA. L. REv. 1418, 1430 (1976).

160. Justice Frankfurter made this point in his concurring opinions in United States v. City of Detroit, 355 U.S. 466 (1955), and United States v. Township of Muskegon, 355 U.S. 484 (1955), and in his dissenting opinion in City of Detroit v. Murray Corp., 355 U.S. 489 (1955). In the City of Detroit dissent he stated:

The danger of hindrance of the Federal Government in the use of its property, resulting in erosion of the fundamental command of the Supremacy Clause, is at its greatest when the State may, through regulation or taxation, move directly against the activities of the Government. . . It is not only that the likelihood of local legislation deliberately or unwittingly discriminatory against government property either by its terms or application may be enhanced. Even a nondiscriminatory tax, if it is expressly laid on government property, is more likely to result in interference with the effective use of that property, whether because of an ill-advised attempt by the tax collector to levy on the property itself or because it is sought to hold the Government or its officers to account for the tax, even if ultimately the endeavor may fail. The defense of sovereign immunity to a suit against government officers for the tax, or a suit to assert title to or recover property erroneously levied upon to satisfy a tax, may in practice be an inadequate substitute for the clear assertion of federal interest at the threshold. 355 U.S. at 504-05 (emphasis added). See also Tribe, Intergovernmental Immunities in Litigation, Taxation, and Regulation: Separation of Powers Issues in Controversies About Federalism, 89 HARv. L. REv. 682, 700-11 and especially 704-05 \& nn. 101-02 (1976). 
issue of the levy's validity in essentially the same way. In each case, the Court's primary concern was whether the tax in question discriminated against or imposed a special burden upon the constitutionally protected interest, and, in the absence of such a finding, the Court sustained the tax. In two of the cases, the Court flatly repudiated prior doctrine that proscribed state taxation without regard to whether it discriminated against or imposed a special burden upon the protected interests; and in the third, it shifted its doctrinal emphasis so as to underscore these considerations. In view of the hundreds of decisions the Court has handed down in this area, it would be premature to conclude that the Court has adopted a more unified approach to determining the constitutionality of the exercise of state tax power under these constitutional provisions. ${ }^{161}$ Nevertheless, there is some evidence to support such a thesis, and it is a development that deserves acknowledgment, if not encouragement. ${ }^{\mathbf{1 6 2}}$

161. The Court's most recent decision in the state tax field, National Geographic Socy. v. California Bd. of Equalization, $97 \mathrm{~S}$. Ct. 1386 (1977), is a reminder that not every Supreme Court opinion addressed to constitutional limitations on state tax power fits neatly into the analytical framework suggested in this article. In National Geographic, the Court held that an out-of-state mail order seller maintaining two offices in the taxing state had a sufficient nexus with the state to justify the imposition of use tax collection liability upon the seller consistent with the due process and commerce clauses. The Court broke no new doctrinal ground in concluding, on the basis of a detailed factual analysis of the relevant precedents, that the Society fell on the taxable side of the sharp line the Court had drawn "between mail order sellers with retail outlets, solicitors, or property within [the taxing] State, and those ... who do no more than communicate with customers in the State by mail or common carrier as a part of a general interstate business." $97 \mathrm{~S}$. Ct. at 1392 (quoting National Bellas Hess Co. v. Department of Revenue, 386 U.S. 753, 758 (1967)). Although the Court adverted to the principles underlying the decisions discussed herein, see $97 \mathrm{~S}$. Ct. at 1391, it is plain that determination of an out-of-state vendor's duty to collect use taxes will continue to depend essentially on the nature and extent of its contacts with the taxing state.

162. The thesis of this Article is likely to be tested as a result of the Supreme Court's agreement to review the decision of the Washington Supreme Court in Association of Washington Stevedoring Cos. v. State Dept. of Revenue, 88 Wash. 2d 315, 559 P.2d 997 (1977), cert. granted, 46 U.S.L.W. 3184 (U.S. Oct. 3, 1977). In that case, the state court held that the commerce and import-export clauses rendered unconstitutional the application of Washington's business and occupation tax to gross receipts from stevedoring activity. The court relied upon the decisions of Puget Sound Stevedoring Co. v. State Tax Commn., 302 U.S. 90 (1937), and Joseph v. Carter \& Weekes Stevedoring Co., 330 U.S. 422 (1947), as a basis for concluding that "[t]he United States Supreme Court obviously views stevedoring as an integrated inseparable part of commerce by sea, and hence absolutely protected." 88 Wash. 2d at $\longrightarrow, 559$ P.2d at 998 . The dissent, relying on the Court's more recent precedents, suggested that the stevedoring cases had been "impliedly overruled," and it observed that nondiscriminatory taxes on interstate commerce had been sustained. 88 Wash. $2 \mathrm{~d}$ at $\longrightarrow 559$ P.2d at 999-1000 (Utter, J., dissenting). The decision of the state court preceded the Supreme Court's decision in Complete Auto Transit by a month. 